ROBERT E. HALL*

Massachusetts Institute of Technology

\title{
Prospects for Shifting the Phillips Curve through Manpower Policy
}

THE CONTEMPORARY PHILLIPS CURVE measuring the tradeoff between inflation and unemployment in the United States is so unfavorable that many economists and most policy makers have reached the conclusion that no combination of inflation and unemployment permitted by the curve is acceptable. The recent policy of the United States has responded to this problem mainly through the imposition of controls on prices and wages. Few economists regard these controls as a satisfactory solution in the long run to the problem of achieving low rates of unemployment at tolerable levels of inflation. There is substantial agreement in the profession that the fundamental cause of the unfavorable Phillips curve is in the failure of labor markets to operate properly. My purpose in this paper is to examine critically the prospects for a long-run attack on inflation and unemployment through treatment of the fundamental causes of the problem. Policies with this goal that operate directly in the labor market are known collectively as manpower policy.

Economists are far from agreement about the precise reasons for the failure of labor markets to perform adequately. In my earlier paper, "Why Is the Unemployment Rate So High at Full Employment?"' I reviewed

* The research reported here was supported by the Manpower Administration of the U.S. Department of Labor and by the National Science Foundation. Neither agency is responsible for the opinions expressed here. I am grateful to Zvi Body and to Steven Shavell for assistance, as well as to members of the Brookings panel for comments.

1. Brookings Papers on Economic Activity (3:1970), pp. 369-402. 
alternative explanations of the unfavorable position of the Phillips curve, looking at the problem as one of explaining the high level of unemployment that remains even when there is sufficient aggregate demand to raise prices at the rate of 3 or 4 percent per year. Any discussion about unemployment must carry a reminder of the way data on unemployment are gathered. The official statistics record as unemployed those who are looking for work, not necessarily those who are out of work. Consequently, it can be a serious mistake to think of unemployment as the difference between supply and demand in a particular labor market. I will return to this point.

One of the oldest theories relating to the Phillips curve involves the notion of sectoral disequilibrium. Of the many regional and occupational labor markets in the economy, some will have excess supply at any point in time because of continual changes in the pattern of supply and demand in the markets. Workers are inhibited from moving from one market to another by the cost of moving and by lack of information about jobs in other sectors. Even so, the theory requires that equilibration take place as time passes; it explains the chronic existence of unemployment by hypothesizing continuing random shocks in labor markets. My examination of the empirical evidence showed that there are important differences in unemployment rates by geographic location, but that these differences are stable over time, even during a period of large increases in aggregate demand and substantial changes in the composition of demand. In my earlier paper I went on to discuss an alternative explanation of the geographical pattern of unemployment. In any event, no convincing empirical case can be made that transitory disequilibrium accounts for a very large fraction of the unemployment that is observed at full employment.

A second explanation of the Phillips curve emphasizes the role of turnover in the labor force in maintaining the pool of unemployed workers. It also emphasizes that the rational worker will devote a reasonable period of time to the process of searching for a new job. One might characterize this as a rigorous theoretical development of the traditional notion of frictional unemployment. Given the high levels of turnover in the economy, the modern search-turnover theory seems to be supported by the data: High rates of unemployment are not caused by the permanent inability of a fraction of the labor force to find jobs. Rather, high rates are associated with the existence of frequent spells of unemployment. Again, I will return to this point. The major limitation of the search-turnover theory is its failure to provide an explanation of the high rates of turnover found in the U.S. 
economy. In this sense it cannot claim to provide a complete account of the problems of labor markets, but it does clarify the nature of the problems. In particular, it makes clear that the traditional theory of structural unemployment needs reformulation: The problem of disadvantaged workers, relative to other members of the labor force, is that they are unable to find stable jobs, not that they are unable to find work at all.

Two bodies of thought seek to explain the observation that certain groups in the labor force have pathologically high rates of unemployment. The first emphasizes considerations on the supply side of the market. According to this view, disadvantaged workers have trouble finding and holding jobs because they lack the background and skills for the jobs available. The second emphasizes characteristics of the demand for labor. It holds that the economy tends to offer too many bad jobs and too few good jobs with high wages and good working conditions, and to systematically exclude disadvantaged workers from good jobs. Neither of these views specifies the link between lack of skills or lack of good jobs, on the one hand, and, on the other, turnover, which I have already indicated is the main source of high unemployment. Why do disadvantaged workers lose or leave their jobs so soon after taking them, granted that they are relatively poor jobs? This remains a central unanswered question in the theory of unemployment.

I distinguish three kinds of manpower policies relating to the diagnoses just discussed. The first attempts to make the labor market function more effectively with the existing patterns of supply and demand. Programs of this kind involve placement activities and counseling of workers looking for jobs and of employers looking for workers. They may also involve schemes for increasing the mobility of workers. A comprehensive program of this sort has just been proposed by Charles Holt, Duncan MacRae, Stuart Schweitzer, and Ralph Smith at the Urban Institute. The first major section of my paper is devoted to a critical review of their program and the theory that underlies it.

The second kind of manpower program attempts to change the pattern of the supply of labor. Federal policy of the past decade has generally taken this form, emphasizing the training and upgrading of disadvantaged workers. Discussion of this kind of policy occupies the second section of the paper.

The third kind of policy tries to influence the composition of the demand for labor, especially by opening up good jobs for disadvantaged workers. 
Federal manpower programs seem to have shifted in this direction, but I will argue that most of the shift is illusory. A close examination of the largest new program uncovers few differences from the traditional training programs that it was intended to replace. I go on to discuss small programs that seem to have been successful in putting disadvantaged workers in good jobs, but I am pessimistic about the prospects for a large-scale federal program of this kind.

Throughout the paper, I attempt to maintain a consistent approach to the measurement of the effect of manpower policies on the position of the Phillips curve. The problem is to distinguish between movements along the curve, which will be induced by any increase in the demand for labor, and true shifts of the curve. Only the latter permit lower rates of unemployment at a given rate of inflation. I make an effort to present estimates of the impacts of alternative policies that are standardized for the inflationary effects of the policies. I do this by choosing a reference level of unemployment, 4.5 percent, and asking what new level of unemployment after the implementation of a particular policy causes the same level of inflation that would exist at the reference level of unemployment in the absence of the policy.

\section{The Manpower Policy Recommended by Holt and His Colleagues}

Any discussion of the aggregate impact of manpower policy must necessarily pay close attention to the recent papers of Charles C. Holt and his colleagues at the Urban Institute, including the report that follows in this issue of Brookings Papers on Economic Activity. ${ }^{2}$ Among economists interested in policies for shifting the Phillips curve, only Holt and his group at the Urban Institute have formulated a consistent theoretical view of the detailed operation of labor markets, applied that theory to make recommendations for manpower policy, and attempted to estimate the aggregate costs and effects of the policies.

The theory underlying the work of Holt and his group can be summarized briefly as follows: There are many labor markets in the economy, distin-

2. Charles C. Holt, C. Duncan MacRae, Stuart O. Schweitzer, and Ralph E. Smith, The Unemployment-Inflation Dilemma: A Manpower Solution (Urban Institute, 1971); "Manpower Programs To Reduce Inflation and Unemployment: Manpower Lyrics for Macro Music," Institute Paper 350-28 (Urban Institute, 1971; processed); and "Manpower Proposals for Phase III," this volume, pp. 000-00. 
guished by location, occupation, and characteristics of workers. In each market, workers continually flow into unemployment because of quits or layoffs or because of the entrance of new workers. Unemployed workers must spend time searching for jobs, gathering information about openings, wages, and working conditions, or waiting for jobs to become available. Even when the market is in stochastic equilibrium, in the sense that there is no unexpected upward or downward pressure on the wage level, the natural turnover in the labor force will cause a positive unemployment rate. When unemployment falls below this level and employers find it harder to fill vacancies, the wage rises. Conversely, when unemployment rises above the equilibrium level, wages fall. However, the process is asymmetric: The inflation caused by 1 percentage point of unemployment below the equilibrium level is greater in degree than the deflation caused by 1 percentage point of unemployment above the equilibrium level. In the aggregate, the rate of change of the wage level averaged over all markets depends not only on the average unemployment rate but also on the dispersion of rates among the markets. For the same average level of unemployment, more inflation develops if there is substantial variance in the unemployment rates of the various markets than if they all had the same rate.

In "Manpower Programs," Holt and his colleagues propose four kinds of policies:

1. Those that improve both the speed of matching workers and jobs and the quality of the matches. For a given flow of workers into unemployment, these policies will decrease the unemployment rate by shortening unemployment for each individual. Further, better matches should last longer and therefore reduce the flow into unemployment.

2. Those that reduce turnover in groups where it is particularly high, especially teenagers.

3. Those that increase the supply of workers in markets where labor shortages exist, either by shifting them from other markets or by bringing them into the labor force. This reduces the dispersion of unemployment and allows a lower average unemployment rate for any given rate of inflation.

4. Those that break down institutional barriers between labor marketsunion restrictions on entry, restrictive occupational licensing, and so forth. These barriers increase unemployment by increasing the dispersion of unemployment among occupations and reducing the efficiency of search.

The principal theme of the recommendations Holt and his colleagues 
make is that the existing manpower programs of the federal government are basically on the right track, but that they should be expanded severalfold and devoted less exclusively to serving disadvantaged workers. Holt's group emphasizes the principle that improvements in the efficiency of labor markets, especially those that relieve shortages, yield an indirect benefit for disadvantaged workers by permitting an overall tightening of labor markets through monetary and fiscal policy without inflation. Although this principle is recognized in discussions of the macroeconomic theory of inflation, it is often overlooked in evaluating the effects of manpower programs.

\section{IMPROVING THE SPEED AND QUALITY OF MATCHING}

The first part of the program proposed by Holt and his associates involves a very substantial increase in the most traditional and uncontroversial activity of the federal government in labor markets, the Employment Service.

They propose a tripling in the number of counselors and interviewers in the Employment Service and their upgrading through a 25 percent salary increase. These proposals would raise the cost of the service from its present level of about $\$ 600$ million to $\$ 2.4$ billion. The overall effects of this increase, according to their estimates, would be a decrease of 5 percent in the average time an unemployed worker requires to find a job and another 5 percent decrease in the flow of workers into unemployment through quits and layoffs. Centralization of information about job openings through computerized matching and the increase in the staff of the Employment Service would speed up the process of finding jobs, and improved counseling of workers and employers would reduce the frequency of quits and layoffs at a given level of aggregate demand.

It is hard to quarrel with a figure as low as 5 percent of anything, but the two figures taken together imply a not insubstantial reduction of 0.5 pointto 4.0 percent in their example-in the overall unemployment rate. In the present case I am seriously concerned that their estimates of the effects of their programs on the unemployment rate err on the optimistic side. Even within the general view of the operation of labor markets held by the authors (I will discuss my objection to this view presently), there is no theoretical presumption that the policies recommended will reduce rather than increase the unemployment rate. Their goals of speeding up placements and reducing quits and layoffs are in direct conflict with one another: The easier 
it is to find a new job the more likely is a worker to quit, and the easier it is to fill a position subsequently the more likely is an employer to lay a worker off. The authors admit this candidly, but nonetheless they project a decrease in quits and layoffs as a result of their policy.

Students of the labor market agree that if workers could be better matched to jobs, the unemployment rate would be lower. At unemployment rates under 5 percent, a good portion of those unemployed are apparently moving from one job they don't like to another, or are looking for the least unsatisfactory job available after having been out of the labor force. ${ }^{3}$ The question at hand is whether very much can be done to improve the quality of matching jobs and workers through expansion and reorganization of the Employment Service. Since improved matching not only is supposed to bring about a 5 percent reduction in turnover but also must counteract the tendency of faster placement to stimulate turnover, Holt's program puts a great deal of faith in the ability of counselors and computers to improve and speed the allocation of workers to jobs. Quite apart from the obstacles to reorganizing and redirecting as firmly entrenched a bureaucracy as the Employment Service, ${ }^{4}$ there are serious doubts about the usefulness of a substantial expansion of centralized placement services. The benefits of better matching are chiefly private and accrue to the individual worker in the form of high wages, a more satisfying job, and less unemployment, and to the employer in the form of reduced costs of turnover. ${ }^{5}$ If large as yet unrealized returns could be made by listing jobs and counseling workers, profits would be available to private entrepreneurs in the placement business. The fact that the existing placement industry is so small and serves

3. See Hall, "Why Is the Unemployment Rate So High?" pp. 388-96.

4. A complete and pessimistic account is available in Stanley H. Ruttenberg and Jocelyn Gutchess, The Federal-State Employment Service (Johns Hopkins Press, 1970).

5. This is not to say that no externalities operate in the labor market. By quitting, the worker can impose a cost on his employer beyond what he bears himself and similarly the employer can impose a cost on the employee by firing him. But these externalities are local and can be internalized by a suitable arrangement between employer and employee. This is one of the main themes of Peter B. Doeringer and Michael J. Piore, Internal Labor Markets and Manpower Analysis (Heath, 1971). In addition, there may be global externalities: Better placement might have a general social payoff in the form of reduced expenditures for police protection and the like. Only the latter is a convincing argument for public subsidy. Finally, the placement industry as conceived by Holt is a natural monopoly because it operates at increasing returns to scale, so any large placement effort should be at least regulated by the government. This does not affect the argument that the existence of private placement activities sharply limits the extent of possible unrealized benefits in placement programs. 
only a few specialized markets suggests to an economist that in most markets little is to be gained from formal placement agencies. What is known about the behavior of individual workers confirms this suspicion: By and large, workers find jobs by consulting their friends and inquiring at factories and businesses, and have relatively little use for the Employment Service. ${ }^{6}$ Holt and his associates interpret this as evidence that the Employment Service should be reformed, while I am suggesting that perhaps the whole idea of a central placement service is not a very useful one except in certain kinds of markets.

Why might this be so? In the first place, labor markets are often rather different from the model that the proponents of an expanded Employment Service have in mind. Only a fraction of the new jobs that become available in a given month are thrown open to the public in the way suggested by the advocates of increased placement efforts. Most employers fill jobs without recourse to the open market for one of three reasons: (1) they do not want to, (2) they are not allowed to, or (3) they do not need to.

Employers choose not to recruit from the open market because they already have much better information about a group of workers-their own employees-who, furthermore, have accumulated training and experience specific to the firm's activities. The internal labor market, where jobs are filled solely by promotion, is a pervasive characteristic of a good fraction of the economy, and represents a rational and efficient response to the technology of production. ${ }^{7}$ Firms are prevented from recruiting in the open market by a wide variety of institutional and governmental restrictions. Perhaps the most important of these are union limitations on entry and government licensing. Finally, firms find it unnecessary to recruit in the open market when the jobs they offer pay more than is necessary to attract enough workers without active recruitment. If the personnel office already possesses a long waiting list, as is true in many industries except in periods of extremely tight labor markets, it is literally not worth the trouble of informing the Employment Service when a job opens up. A firm pays more than it must only under duress; without constraints on its wage policy, it would reduce wages until the waiting list shrank close to zero and would

6. See Harold L. Sheppard and A. Harvey Belitsky, The Job Hunt (Johns Hopkins Press, 1966), and Peter Doeringer (ed.), "Low Income Labor Markets and Urban Manpower Programs: A Critical Assessment," Joint Harvard-MIT report submitted to the Manpower Administration (reproduced by National Technical Information Service, 1969).

7. This view and its implications are fully developed in Doeringer and Piore, Internal Labor Markets. 
take advantage of the then useful (and free) Employment Service. Labor unions and other powerful institutions have as one of their main purposes forcing firms and other employers to pay more than is necessary to attract labor. There is little the Employment Service can do to help these employers or to place unemployed workers in jobs with them.

Together, the three reasons for the failure to recruit from the open market cut off a large portion of the jobs in the economy from assistance by the Employment Service. Starting from data on internal and external labor markets presented by Doeringer and Piore, I have attempted to estimate in a very rough way the portion of total employment in markets to which the Employment Service might make a contribution. The classification appears in Table 1. Almost two-thirds of all employment is in markets where the Employment Service has little potential. Of these markets, those for military services, workers in craft unions, proprietors and self-employed family workers, and professionals presumably are noncontroversial. Public enterprises are included because of the strength of worker associations, especially among postal workers, industrial unions for the reason indicated above, and large enterprises because of the strength of internal labor markets. The

\section{Table 1. Employment Markets, by Usefulness of U.S. Employment Service, 1965}

Likelihood of usefulness of Employment Service and type of market

Employment Service likely to be useful

Institutions (hospitals, universities, museums, etc.)

Small enterprises

Farm laborers

Domestic workers

Odd job, service, and repair work

Employment Service unlikely to be useful

Military services

Public enterprises

Union workers in large enterprises

Nonunion workers under industrial agreements

Workers outside the bargaining unit in large enterprises

Large nonunion enterprises

Workers in craft unions

Proprietors and self-employed family workers

Self-employed professionals
Percent of total employment
34.7

2.9

27.0

1.5

2.4

0.9

65.1

3.2

11.8

11.8

1.3

7.0

7.0

9.4

12.0

1.6

Source: Peter B. Doeringer and Michael J. Piore, Internal Labor Markets and Manpower Analysis (Heath, 1971), Table 1, p. 42. Classification on the basis of the usefulness of the Employment Service was made by the author. The figures do not add to 100.0 because of rounding. 
last is subject to qualification since not every employee of a large enterprise is on a promotion ladder, and some large enterprises fill entry-level jobs by active recruitment in the open market. However, large companies are often sufficiently well known that job hunters check directly with them, so that listing with the Employment Service would improve dissemination of information about their openings only very slightly.

It is small enterprises and their prospective employees that are the natural clients of the Employment Service. Since the service is already of considerable help to this market, a dramatic increase in its scale of operation would tend more to intensify its assistance in placing workers with small businesses and individuals than to extend its coverage of markets. Another trait of the Employment Service is apparent from Table 1. It cannot generally place workers in the good jobs in the economy. Pleasant working conditions, high wages, and chances for promotion are much more common in the second category than in the first. Even with a large expansion of the Employment Service, better matching of workers and jobs clearly means finding for each worker the least unsatisfactory of the poor jobs listed by the service. If, in reaction, the small faith workers have in the ability of the service to find them jobs fails to grow, the prospect for reducing unemployment by expanding the service is rather poorer than Holt and his colleagues have suggested.

Since Holt, MacRae, Schweitzer, and Smith have attempted to estimate the effect of their policies, I will do the same, but with their misgivings redoubled. For their proposed expansion of the Employment Service, my guess is that faster placement of unemployed workers in jobs in small enterprises would reduce the aggregate unemployment rate by 0.1 point. Further, I suspect that faster placement would stimulate turnover by about the same amount that improved matching would reduce it, so that the total effect of the program on unemployment would be 0.1 point.

\section{PLACING TEENAGERS}

The second part of the program of Holt's group is a direct attack on unemployment in the demographic group with much the highest unemployment rate, teenagers. The diagnosis underlying the program is, I think, the correct one: The problem of high unemployment among teenagers (at full employment) is not that they have trouble finding jobs but that they have trouble keeping them. The duration of their unemployment is low, but its 
frequency is high. Holt believes that a major cause of this problem is that teenagers receive little preparation in school for work, and almost no information about the sorts of jobs available when they leave school. As a result, they move rapidly from one job to another, finding out in a rather expensive way what kind of work they like.

Holt and his colleagues propose that the educational system be modified to permit students in the ninth through twelfth grades to participate in federally supported work-study programs. They propose a federal expenditure of $\$ 1,000$ per student to provide after-school and summer employment for a million high school students, and a large increase in vocational counseling for teenagers. They estimate that these policies would reduce unemployment among teenage students while they are attending school from 600,000 to 100,000 , and would reduce turnover among teenagers who are not in school by about 17 percent. These figures represent reductions of 500,000 and 100,000 in the number of unemployed teenagers, and together would decrease the aggregate unemployment rate by 0.7 point.

The first of these estimates, however, appears to be inconsistent with one of the important conclusions of Holt's theory. Unemployment of teenagers is not simply the difference between the supply of labor they offer and the demand for it. If the program generated a net increase of 750,000 or even a million jobs for teenagers, unemployment would not shrink to zero. There are over 11 million youths aged 16,17, and 18 at the moment. If a million of them were in a work-study program, there would surely be a level of turnover among the remaining 10 million not too different from what it is now. For example, teenagers intending to go to college would probably not be interested in the work-study program, yet they might very well look for a job after school and thus appear in the statistics as unemployed. At the very outside, unemployment of teenagers in school might be reduced by 100,000 by the work-study program. There are 15 million teenagers in grades 9-12, of whom 600,000 , on the average, are looking for work when the overall unemployment rate is 4.5 percent. If the work-study program took teenagers at random, and if the rate of turnover and average duration of unemployment of those not enrolled remained the same, then unemployment would fall by 6.7 percent ( 1 million out of 15 million) of 600,000 , or 40,000 . If the program were successful in recruiting unemployment-prone teenagers, or if it tightened the market for teenagers and thus reduced the duration of unemployment, its effect might be somewhat larger. In the long run, relatively little tightening is likely to occur because as jobs become 
easier to find, on the one hand, additional teenagers are likely to enter the labor force, and as teenage workers become harder to find, on the other hand, employers will begin recruiting in other markets.

The estimate of the reduction in unemployment of teenagers out of school suffers from many of the defects that compromise the estimate for the general expansion of the Employment Service. What is the prospect for such a large reduction in unemployment of teenagers through vocational counseling when the counselor can only identify the least unsatisfactory of a set of unattractive jobs? The element that seems to be missing is any discussion of the need to open up good jobs, especially for disadvantaged teenagers. In any case, the Urban Institute estimate of the impact of this program suffers from the technical defect that it is not standardized for its inflationary effect. Part of the reduction in unemployment they ascribe to the program is simply movement along the Phillips curve, not a shift in it. A more reasonable estimate of the effect of the proposed policies for teenagers on the overall unemployment rate might be 0.2 point after allowance for its inflationary effect. In spite of this, I think the proposal to emphasize work-study programs has much merit as an alternative to the existing system of classroom and vocational instruction in high schools.

\section{REDISTRIBUTING THE LABOR FORCE}

The third component of the proposal of Holt, MacRae, Schweitzer, and Smith is a set of programs for reducing the dispersion of unemployment rates among the many labor markets in the economy. They focus separately on two dimensions distinguishing the markets, occupation and geographical location. Three basic policies are suggested for reducing the occupational dispersion of unemployment: retraining current members of the labor force to qualify for jobs in markets where unemployment is lower than the average, restructuring jobs, and inducing the entry of women with children into labor markets where shortages exist. The first involves the creation of 1.1 million new training slots-half allotted to women-to teach workers to fill jobs in markets with shortages $(70,000$ such slots exist in the present training establishment). On the employers' side, they propose the addition of 4,000 industrial engineers and psychologists to the staff of the Employment Service to advise on methods for substituting workers in plentiful supply for those in short supply. Finally, they propose an annual subsidy of $\$ 1,300$ per child for child care which, they project, will stimulate the entry 
into the labor force of 1.37 million women with 2.75 million children. Child care would be available only to women qualified to be trained for jobs in tight markets; this qualification would be implemented by locating the child care center at the place of employment or by linking the subsidy to a woman's occupation.

Holt and his colleagues do not give a direct estimate of the effect on unemployment of their program for alleviating shortages by occupation. Instead, they make the remarkable, and to me untenable, assumption that their programs would totally eliminate dispersion in unemployment rates. To translate this into unemployment terms, they fit a simple Phillips curve in which the dispersion of unemployment as well as its average level appears, and calculate the amount by which the average level of unemployment could be reduced, assuming that inflation were constant, if dispersion were eliminated. The results of this calculation are impressive: Elimination of dispersion by occupation could reduce the average level of unemployment by 1.1 points, about a quarter of the 4.5 percent reference level for their calculations. I find this procedure defective in two respects. First, the analysis requires the crucial assumption that the intercept of the aggregate Phillips curve is unaffected by the redistribution of the labor force that they propose. That intercept is a weighted average of the intercepts of the Phillips curves for the various occupational markets, where the weights are the shares of total employment in each occupation. The weighted average will remain unchanged after the redistribution of the labor force if the distribution of employment remains unchanged or if all of the individual intercepts are the same. The former contradicts the search-turnover theory, which predicts that the effect of moving a group of workers who happen to be unemployed at a moment in time is no different, after a few months, from the effect of moving workers who happened to be employed then. The theory predicts that the effect of removing workers from a market is to reduce both unemployment and employment in the market. The latter justification for an unchanged intercept is clearly not supported by the data. Some occupations involve inherently higher unemployment than others, so their intercepts are higher. I conclude that the assumption of an unchanged intercept of the aggregate Phillips curve is untenable, and that the large estimate of the effect of redistributing the labor force among occupations is open to serious question on this account.

Second, even if the calculation of the effects of the program were technically correct in terms of the theory advocated by the Urban Institute 
group, the program itself does not make good sense. It proposes to shift the aggregate Phillips curve to the left by causing the rates of wage inflation to vary substantially over occupational groups. Occupations where the Phillips curves have large intercepts would have high rates of inflation, while those with small intercepts would be required to have low rates of inflation, or perhaps even falling wages. For example, their recommendation taken literally implies that the rate of increase of the wages of construction workers should be higher than it is now (though it is high already) and that the rate of wage increase for professional and technical workers should be lower than it is now (though it is low already). In order to maintain the more favorable aggregate Phillips curve achieved this way, it would be necessary to maintain the differentials in the rates of wage increase permanently, thus creating growing disparities in the levels of wages. This strikes me as neither practical nor desirable.

I think that the emphasis of the Urban Institute group on elimination of occupational differentials in unemployment is quite mistaken, and that they should return to the more limited and traditional goal of identifying and eliminating specific bottlenecks in the labor market. I estimate that a realistic program of this kind could reduce the overall unemployment rate by about 0.1 point after standardization for inflation.

Holt and his colleagues also propose a program for reducing the geographic dispersion in unemployment by subsidizing the movement of workers from slack to tight markets. Their analysis is essentially parallel to that for occupational dispersion, and suffers from the same overstatement of the potential effects of the policy. In addition, there is a certain amount of double-counting in their evaluation of the two programs: To the extent that the dispersion of unemployment among states is caused by the dispersion of employment by occupation among the states, the first program would reduce the dispersion among states as well, leaving less for the second program. I am inclined to reduce their estimate of the effect of the program from 0.3 point to zero.

\section{LOWERING INSTITUTIONAL BARRIERS}

The last set of programs suggested by Holt, MacRae, Schweitzer, and Smith deals with what strikes me as the heart of the problem-institutional barriers in the labor market. A certain ambiguity surrounds their discussion of this topic because it does not fit easily into their theoretical framework. 
Within that framework, barriers to mobility between markets have an adverse effect on the Phillips curve by increasing the dispersion of unemployment and decreasing the efficiency of search - that is, union restrictions on entry are bad because a transitory tightening of the market cannot be alleviated by the free movement of workers from other markets. Holt and his colleagues do not hold to this excessively narrow view of the effects of these institutions. They recognize that the institutions operate to create a chronic excess supply in their markets, effectively cutting off entry to a good portion of the total number of jobs in the economy. They do not make any concrete suggestions for breaking down institutional barriers, nor add anything to their list of estimated reductions in unemployment on this account.

Table 2 presents a revised version of the effects Holt and his group expect their policies to have in an economy with the same level of inflation that would correspond with 4.5 percent unemployment in 1972.

I conclude that relatively little improvement in unemployment can be expected from the very large expansion of traditional manpower programs advocated by Holt and his colleagues.

Table 2. Alternative Estimates of Potential Reduction in Unemployment through Selected Manpower Program Proposals

\begin{tabular}{|c|c|c|c|c|}
\hline \multirow[b]{2}{*}{ Program } & \multicolumn{2}{|c|}{$\begin{array}{c}\text { Estimates by Holt and } \\
\text { associates }\end{array}$} & \multicolumn{2}{|c|}{ Present estimates } \\
\hline & $\begin{array}{l}\text { Reduction in } \\
\text { unemployment }\end{array}$ & $\begin{array}{l}\text { Reduction in } \\
\text { unemployment } \\
\text { rate at } 4.5 \\
\text { percent base } \\
\text { (percentage } \\
\text { points) }\end{array}$ & $\begin{array}{l}\text { Reduction in } \\
\text { unemployment }\end{array}$ & $\begin{array}{l}\text { Reduction in } \\
\text { unemployment } \\
\text { rate at } 4.5 \\
\text { percent base } \\
\text { (percentage } \\
\text { points) }\end{array}$ \\
\hline \multicolumn{5}{|l|}{ Expansion of } \\
\hline Employment Service & $10 \%$ & 0.5 & $2 \%$ & 0.1 \\
\hline $\begin{array}{l}\text { Vocational counseling } \\
\text { and teenage work- } \\
\text { study }\end{array}$ & 15 & & 4 & 0.2 \\
\hline Occupational mobility & 25 & 1.1 & $\begin{array}{l}4 \\
2\end{array}$ & 0.1 \\
\hline Geographic mobility & 7 & 0.3 & 0 & 0.0 \\
\hline Total, all programs & $47^{a}$ & 2.1 & $8^{a}$ & 0.4 \\
\hline
\end{tabular}

Sources: Estimates by Holt and associates, this volume, their Table 1, p. 717; Hall estimates-see text for underlying factors.

a. Computed by multiplying components; for example, $0.47=1-(1-0.10) \times(1-0.15) \times(1-$ $0.25) \times(1-0.07)$. 


\section{Reducing Unemployment among Disadvantaged Workers}

The Area Redevelopment Act of 1961 (ARA) marked the start of modern federal policies for dealing selectively with groups in the labor force that suffer from rates of unemployment higher than the average rate. It provided for training programs for unemployed workers in regions with high unemployment. Soon after the ARA was enacted, the Manpower Development and Training Act of 1962 (MDTA) provided two distinct training programs, which are still in operation today: institutional training and on-thejob training (OJT). The latter is now part of the program called Job Opportunities in the Business Sector (JOBS). Modern training programs have come to focus more on disadvantaged workers-blacks, teenagers, and the poorly educated - than on regional unemployment. Less traditional approaches to helping disadvantaged workers were embodied in two wellknown programs associated with the war on poverty: the Neighborhood Youth Corps (NYC) and the Job Corps. Both of these programs provide employment for trainees during their periods of enrollment and give assistance in locating jobs after completion of training. ${ }^{8} \mathrm{~A}$ variety of programs has been instituted more recently with similar objectives; these include the Concentrated Employment Program (CEP), offering a broad range of services to disadvantaged workers; JOBS, offering training and jobs in private industry (discussed in a later section); and the Work Incentive Program (WIN), offering training to adults who receive public assistance.

The magnitudes of these programs are indicated in Table 3, using two different measures: the number of individuals enrolled at the end of the month, averaged over January, April, July, and December 1970, and the number of individuals who enrolled for the first time between July 1969 and June 1970. In most of the programs, the average enrollment is well below the annual flow of new enrollments, indicating a salient feature of these programs: On the average, they retain their trainees for only a few months. It is possible to make a rough calculation of the average duration of a trainee's stay simply by dividing the average enrollment by the flow of new enrollments and multiplying by 12 to convert to months. This measure is accurate for programs that are neither growing nor shrinking, and overstates the average duration for programs that are growing. The results of

8. For a complete history and evaluation of these programs and the MDTA, see Sar A. Levitan and Garth L. Mangum, Federal Training and Work Programs in the Sixties (Ann Arbor: Institute of Labor and Industrial Relations, 1969). 
Table 3. Number and Average Duration of Enrollments for Manpower Training Programs Administered by the Department of Labor, 1970

\begin{tabular}{lccc}
\hline \multicolumn{1}{c}{$\quad \begin{array}{c}\text { Average } \\
\text { number } \\
\text { enrolled, } \\
1970^{\mathrm{a}}\end{array}$} & $\begin{array}{c}\text { Number } \\
\text { of new } \\
\text { entrants } \\
\text { (thousands) }\end{array}$ & $\begin{array}{c}\text { July 1969- } \\
\text { June 1970 } \\
\text { (thousands) }\end{array}$ & $\begin{array}{c}\text { Average } \\
\text { duration } \\
\text { (months) }\end{array}$ \\
\hline Manpower Development and Training Act & & & \\
$\quad$ Institutional training & 51 & 130 & 4.7 \\
$\quad$ On-the-job training & 43 & 91 & 5.7 \\
Neighborhood Youth Corps & & & \\
$\quad$ In school and summer & 179 & 436 & 4.9 \\
$\quad$ Out of school & 32 & 46 & 8.3 \\
Operation Mainstream & 14 & 13 & 12.9 \\
Public Service Careers & 6 & 4 & 18.0 \\
Concentrated Employment Program & 47 & 110 & 5.1 \\
Job Opportunities in the Business Sector ${ }^{\mathrm{b}}$ & 40 & 87 & 5.5 \\
Work Incentive Program & 89 & 93 & 11.5 \\
Job Corps & 20 & 43 & 5.6 \\
$\quad$ All programs & 522 & 1,051 & 6.0 \\
\hline
\end{tabular}

Source: Manpower Report of the President, April 1971, Table 2, p. 38, and Table F-1, p. 299. Average duration is ratio of first to second column multiplied by 12 . Figures are rounded and may not add to totals. a. Average of the numbers enrolled in January, April, July, and December 1970.

b. Federally financed.

this calculation are shown in the third column of Table 3. Except for three fast-growing programs (Operation Mainstream, Public Service Careers, and WIN) and the out-of-school program of the NYC, the estimated durations all lie between four and six months. Any discussion of the long-run effects of these programs must take account of this fact.

Partly because of their short duration, training programs for disadvantaged workers seem almost insignificant when compared with conventional education. On the assumption that the programs that offer training on the job (MDTA-OJT, NYC, JOBS) give six months of instruction per year while the others give twelve months per year, the training programs listed in Table 3 give instruction totaling 4.5 million student-months per year. By comparison, high schools give the 15 million students in grades 9-12 about 135 million student-months per year of instruction. Further, the system of vocational education operated by the Department of Health, Education, and Welfare gives about 8 million student-months per year of training to secondary students (this is included in the 135 million figure for high schools) and about 16 million student-months per year of instruction outside high schools. In terms of months of instruction, the elaborate system of 
programs for training disadvantaged workers is equivalent to increasing the length of stay of each student in high school by about one month.

A detailed evaluation of the impact of existing programs for training disadvantaged workers or of the prospects for reducing unemployment by expanding the programs requires some exploration of the theoretical basis for these programs as weapons against unemployment. The notion of structural unemployment had an important role in the justification of the early programs of the ARA and MDTA. The structural theory held that a condition of disequilibrium existed in certain markets, notably those for poorly trained, unskilled workers, where unemployment persisted because rigidities in wages inhibited the normal process of equilibration. Since the prevailing wage could not be brought low enough to induce employers to hire an unproductive poorly trained worker, it was thought necessary to raise the productivity of these workers to match the wage in order to put them to work.

The development of extremely tight labor markets in the late 1960s revealed that the structural diagnosis was too simple. The view that unemployment is the difference between the supply of labor and the demand for it cannot explain the behavior of labor markets when demand is strong, as I tried to demonstrate in my earlier article in Brookings Papers. Relatively high rates of unemployment were observed among disadvantaged workers in spite of the existence of vacancies in unskilled, low-paying jobs. Unemployment in these markets is a matter of high turnover, not of a chronic shortage of jobs. The remedy of the structuralists still seemed relevant, however, since an unskilled worker who was frequently unemployed because he could not be induced to stay on a low-paying job, might stay permanently on a higher-paying job for which a training program might qualify him. Thus as labor markets tightened during the 1960s the rationale of training programs changed from one of qualifying workers for any job at all to one of qualifying them for good jobs.

\section{ATTEMPTS AT EVALUATION}

A number of economists have attacked the problem of measuring the effects of training programs. ${ }^{9}$ The results have been almost uniformly fa-

9. Einar Hardin presents a careful review of nine studies in "Benefit-Cost Analyses of Occupational Training Programs: A Comparison of Recent Studies," in G. G. Somers and W. D. Wood (eds.), Cost-Benefit Analysis of Manpower Policies, Proceedings of a North American Conference (Kingston, Ontario: Queen's University, Industrial Relations Centre, 1969), pp. 97-118. 
vorable to the programs, in the sense that the estimated benefits-mainly increased income to the trainee-exceed, often by several times, the estimated costs-forgone earnings of the trainee and operating costs of the program. An important study by Earl Main ${ }^{10}$ attempts to estimate the effects of institutional training under the MDTA. Of the many investigators who have made estimates of this type, Main pays the closest attention to the methodological problems that arise, of which the problem of choosing a control group is the most serious. Main began with a random sample of 1,197 former trainees from forty-nine sample areas. In order to assess the effect of the program, he compared the employment and earnings of this group after training with those of a control group of similar individuals who did not receive training. Interviewers selected members of the control group from among friends of the trainees who were unemployed at the time that the training program began. This method yielded 585 controls; an additional 340 were selected by canvassing the neighborhoods where the trainees lived. The control group was reasonably well matched with the group of trainees in respect to race, sex, and age, but there was a substantial difference in educational attainment: 49 percent of the trainees were graduates of high school, against only 32 percent of the controls. In order to adjust for this and other differences in the compositions of the two groups, Main used a regression model with dummy variables for the following characteristics: sex, education, age, race, previous unemployment, whether or not the individual was the main earner in the family, region, marital status, and number of unmarried children under 18 . He also included income per capita of the state where the individual lived. In addition, of course, he used a dummy variable indicating whether or not the individual was a trainee. He studied three left-hand variables: weekly wages for individuals at work, weekly family income for all individuals whether working or not (apparently individual income was not recorded), and the percentage of the time employed since the end of the training period. He found, first, no effect of training on weekly wages; second, an increase of $\$ 10.08$ per week in income for families that have trainees; and third, a difference of 11 to 22 percentage points in the employment rate for trainees.

These results are only slightly less optimistic than those of the costbenefit studies mentioned earlier. But Main himself cautions against too optimistic an interpretation of them:

10. "A Nationwide Evaluation of M.D.T.A. Institutional Job Training," Journal of Human Resources, Vol. 3 (Spring 1968), pp. 159-70. 
The major unresolved question is how much of the estimated net effect of training on employment is really due to some other variable not included in the analysis. ... It is probable that motivation, intelligence, or other factors have some contribution to make. Those who want jobs the most and who have the best minds might be most likely both to find employment and to use every available means to obtain employment, including MDTA job training courses. Therefore, the true effect of training on employment may well be smaller than the estimate given in this report. ${ }^{11}$

Some evidence reported by Main indicates that this warning must be taken very seriously. First, a problem arises in the manner of selecting the sample of trainees: Only 79 percent of those selected for study could be located when the interviews were made more than a year after training was completed. The remaining 21 percent almost certainly had a less favorable employment experience on the average, since an unemployed person is more likely to move without leaving a forwarding address. No similar attrition took place in the control group, since it was selected at the time of the interviews. The average employment rate of the trainees was apparently about 65 percent. ${ }^{12}$ If the employment rate for the trainees that could not be located were, say, 30 percent, then the average employment rate for all trainees would be 58 percent. The difference of 7 percentage points is a substantial fraction of the estimated effect of training on the employment rate of 11 to 22 points.

Second, the difference in the average educational attainment of the two groups is disturbing. The effect of education itself is removed through the use of regression, but the magnitude of the difference suggests the presence of other differences between the two groups of precisely the sort that Main indicates. If differences in motivation, intelligence, and the like are not strongly correlated with the observed characteristics, Main's conclusion needs serious qualification.

The obstacles to scientific evaluation of training programs are fundamental and serious. Even a well-conceived and executed study such as Main's does not make a convincing case that training programs affect unemployment at all. Still, in the absence of knowledge of the effect of the programs on individuals, it is worth investigating the magnitude of the improvement in the aggregate Phillips curve that might result from a program

11. Ibid., p. 169.

12. By employment rate, I mean the fraction of the trainees who are employed. Not all trainees were in the labor force. 
that had a known effect in decreasing the unemployment of individual trainees. The problem of translating individual into aggregate effects has been a bothersome one in the literature on the evaluation of manpower policies. Einar Hardin's review, cited earlier, contains a mystifying discussion of "vacuum," "displacement," and other effects that is an attempt to deal with the secondary impact on the economy of programs for upgrading workers. The newly trained worker may displace another worker, or if he was previously employed, another untrained worker may take his place when he moves up. For my purposes, the appropriate way to study this problem is in terms of the shift in the Phillips curve induced by a training program. In particular, I seek to calculate the reduction in the average unemployment rate made possible by training, with the inflationary pressure in the labor market held constant.

\section{AN ILLUSTRATIVE MODEL}

I think it is useful in approaching this problem to work out the implications of a simple model of the labor market that has only two markets, one for ordinary workers and the other for disadvantaged workers. Following Holt, I will assume that the rate of change of wages in each market, $\dot{w}_{1}$ and $\dot{w}_{2}$, responds only to the corresponding unemployment rates, $u_{1}$ and $u_{2}$, in a way described by a pair of simple Phillips curves:

$$
\dot{w}_{1}=\frac{b_{1}}{u_{1}}-a_{1}
$$

and

$$
\dot{w}_{2}=\frac{b_{2}}{u_{2}}-a_{2} .
$$

If both rates of wage increase are constant at a reference level, $k$, which I will hold fixed for the rest of the analysis, then

$$
u_{1}=\frac{b_{1}}{k+a_{1}}
$$

and

$$
u_{2}=\frac{b_{2}}{k+a_{2}} .
$$

For example, if $a_{1}=8, a_{2}=2, b_{1}=b_{2}=42$, and $k=4$ percent per year inflation, then $u_{1}=3.5$ percent unemployment among ordinary workers, 
and $u_{2}=7$ percent unemployment among disadvantaged workers. If disadvantaged workers are, say, 29 percent of the labor force, then the average unemployment rate is 4.5 percent. Now suppose that some of the disadvantaged workers are upgraded and enter the market for ordinary workers; then the unemployment rate will fall and the rate of inflation rise in the market for disadvantaged workers, and just the opposite will occur in the market for ordinary workers. As the ratio of $w_{2}$ to $w_{1}$ increases as a result, the demand for ordinary workers will increase relative to that for disadvantaged workers. Eventually the two-to-one relationship between $u_{2}$ and $u_{1}$ will be restored. If aggregate economic policy is adjusted throughout this period to maintain the same average rate of inflation, then the rate of inflation in both markets will be the reference level, $k$, at the conclusion. Equations (3) and (4) indicate that the two unemployment rates, $u_{1}$ and $u_{2}$, will have their old values at the end of the adjustment as well. What has changed in the economy? First, the average unemployment rate, $u=$ $(1-d) u_{1}+d u_{2}$, has fallen since $d$, the fraction of the labor force that is disadvantaged, has fallen. Second, the real output of the economy has increased. Third, the wage level of the remaining disadvantaged workers has increased. ${ }^{13}$

The preceding argument has suggested that the experience of individual workers can be used to estimate the aggregate effect of training programs on the unemployment rate (holding the rate of inflation constant) without any adjustment for the response of the economy to the training programs. Partial and general equilibrium coincide. But the empirical studies cited earlier do not support an optimistic view of the aggregate effects of these programs. They suggest that, at its best, an expanded program for training disadvantaged workers, operating for several years, might remove 8 percent of them from their disadvantaged status. This corresponds to a reduction of about 0.02 in $d$, and to a reduction from 4.50 to 4.42 in the average unemployment rate. No plausible alternative set of parameters in this simple model yields any substantial reduction in the overall unemployment rate from a policy that reduces $d$ by 0.02 . For example, if $a_{1}=13.3$ and $a_{2}=$ 0.33 , then $u_{1}=2.42$ and $u_{2}=9.69$. A reduction in $d$ from 0.286 to 0.263 (8 percent) reduces $u$ from 4.50 to 4.33 . Whatever their merit as weapons

13. This assumes that the parameters $a_{1}, a_{2}, b_{1}$, and $b_{2}$ of the Phillips curves do not depend on the levels of the two wages. Alternatively $a_{1}$ might decrease and $a_{2}$ increase as $w_{2} / w_{1}$ increased. It is not possible to state in which direction this would change the conclusion. 
against poverty, training programs cannot bring about a substantial shift in the Phillips curve.

\section{The Shortage of Good Jobs}

Even during the period of extremely tight labor markets from 1966 to 1969, one frequently heard, especially from black leaders, of the urgent need for more jobs, and of the possibility, if these jobs were provided, of the reduction of certain critically high unemployment rates to levels more consistent with social stability. I tried to show in my paper, referred to above, that the problem was not that workers in groups with high unemployment have trouble finding jobs but that they have trouble keeping them. In other words, the simple diagnosis of groups of workers unable to find any jobs at all even when labor markets in general are tight is untenable. Was the passionate demand for more jobs in the late sixties entirely spurious? The answer to this question is of considerable importance because even more today than at that time, proposals for the creation of jobs through subsidy or direct employment receive serious consideration in Congress.

In the late sixties several economists began to work out a resolution of the paradox of a shortage of jobs in an overheated economy. The resulting body of thought is somewhat loosely called the "dual theory." 14 The duality is between two sectors of the labor market: the primary sector, offering good jobs with high wages, satisfactory working conditions, stability, and prospects for promotion, and the secondary sector, offering bad jobs with poor wages and conditions, frequent layoffs, and no hope of advancement. A favored portion of the labor force, particularly adult white males, enjoys the benefits of employment in the primary sector, while the rest-women, teenagers, and members of minorities-suffer from confinement to the secondary market, where, in particular, a great deal of turnover and consequent unemployment are observed. The problem, then, is not a shortage of jobs, but a shortage of good jobs. The force of this theory as an empirical generalization cannot be denied. For example, it predicts not only that

14. David M. Gordon gives a complete account of the development of the dual theory in "Economic Theories of Poverty and Underemployment" (January 1971; processed), pp. 69-91.

The leading proponent is Michael J. Piore; see his "Jobs and Training," in Samuel H. Beer and Richard E. Barringer (eds.), The State and the Poor (Winthrop, 1970), and Doeringer and Piore, Internal Labor Markets. 
white males will have higher wages than the other race-sex groups, but that their wages will rise more with age. Both of these predictions are strikingly confirmed in the results depicted in Figure 3 of my earlier paper. ${ }^{15}$ The dual theory has struck such a responsive chord among economists and others that it has had an important role in the diagnoses of the problems of modern labor markets presented by the administration and the Committee for Economic Development. ${ }^{16}$

To qualify as a theory, the dual theory must go beyond an empirical generalization to a deeper explanation of what is observed. In particular, it must deal with the objection that the forces of the market would tend to remove any disparity in wage rates between the two sectors. If labor were cheaper in the secondary market, the objection goes, the profit-maximizing entrepreneur would discharge his primary workers and hire only from the secondary market. The shift in demand would continue until the wage rates and other costs of labor were equalized and the distinction between the primary and secondary markets abolished. The dual theory must invoke some force, counteracting the natural force of the market, to explain the continued existence of a differential in wages between the markets. The writings of Piore and others ${ }^{17}$ have emphasized three basic explanations of the duality of the labor market: restrictive practices, discrimination, and low productivity of secondary workers because of their previous experience in the secondary market.

The principal restrictive practice discussed by Piore is occupational licensing. For example, a young black finds it hard to enter the skilled trades because licensing boards act in the interest of already licensed workers to make it as difficult as possible for employment to increase. To an economist, the main purpose of licensing appears to be to translate an increase in demand for a given trade into an increase in wages rather than in employment.

Piore distinguishes two kinds of discrimination against secondary workers, discrimination pure and simple and statistical discrimination. Dis-

15. "Why Is the Unemployment Rate So High?" p. 394. For more details see my "Wages, Income and Hours of Work," in Glen Cain and Harold Watts (eds.), Income Maintenance and Labor Supply Econometric Studies (University of Wisconsin, Institute for Research on Poverty, forthcoming).

16. Manpower Report of the President, April 1971, Chap. 3; Committee for Economic Development, Training and Jobs for the Urban Poor (CED, 1970).

17. Piore, "Jobs and Training," and Doeringer and Piore, Internal Labor Markets, Chap. 8. 
crimination pure and simple excludes blacks and other workers from primary employment because of the prejudices of employers, or, perhaps more important, of employees. ${ }^{18}$ Statistical discrimination is a more subtle phenomenon. If employers have trouble identifying productive workers, they may rely on characteristics, notably skin color, that have nothing to do with productivity but that are correlated with it. Thus an exceptional black worker has difficulty getting a good job partly because employers will not be able to identify him as exceptional and will assume that he is closer to the average of all blacks than he is in fact. Where information is hard to get, this kind of behavior on the part of employers is perfectly rational. As Kenneth Arrow has pointed out, the existence of statistical discrimination removes a good part of the incentive for any individual black worker to improve his own productivity..$^{19}$ There may be a self-sustaining equilibrium in which blacks receive lower wages and have lower productivity for no reason other than this vicious circle.

Finally, Piore observes that entrapment in the secondary market causes workers to acquire habits of work that are inappropriate for primary jobs, and that are difficult to shed when they are offered good jobs. In particular, a secondary worker has a more casual devotion to his job, reporting for work late or not at all on some days, and quitting without any good reason, often within months of taking the job. Piore emphasizes that it is habits of work and attitudes about the job, not so much the technology of production or the specific skills of the worker, that distinguish the primary from the secondary market.

Of the three forces tending to maintain the duality of the labor market, only restrictive institutions and discrimination are fundamental causes. The damaging effect of secondary jobs on secondary workers tends to reinforce these causes, and would preserve the duality for a considerable length of time if restrictive institutions and discrimination could be eliminated, but it is not a basic cause and could not account for the duality of the labor market by itself. Thus, starting from the empirical datum that the secondary

18. The mere existence of prejudiced employers or employees is not necessarily harmful to the wages of minority members, as Gary S. Becker has observed in The Economics of Discrimination (University of Chicago Press, 1957), p. 37. But even the most refined estimates of the differential between the wages of similarly qualified whites and blacks suggests that it is substantial; see Michael D. Hurd, "Changes in Wage Rates between 1959 and 1967," Review of Economics and Statistics, Vol. 53 (May 1971), pp. 189-99.

19. "Some Models of Racial Discrimination in the Labor Market," RM-6253-RC (RAND Corporation, 1971; processed). 
market or something like it exists, Piore's theory differs from, say, the theory that disadvantaged workers lack skills, in asserting that the major problems of the labor market would disappear through time if discrimination and restrictive institutions were eliminated.

The proponents of the dual theory of the labor market pay little attention to the role of labor unions in maintaining the shortage of good jobs. Yet this subject merits investigation, since, among blue collar workers, the distinction between union and nonunion jobs is almost the same as that between primary and secondary jobs. Unions can create an artificial scarcity of jobs in two ways: direct control over entry to an occupation, common only in craft unions, or indirect control through the wage rate, the usual case in industrial unions. For example, there is a shortage of jobs as electricians for the clearly visible reason that the number of apprentices is closely controlled. There is a shortage of jobs as automobile workers for the more subtle reason that the United Auto Workers have succeeded in negotiating a wage high enough so that the automobile makers, who make the decision about hiring and firing, decide to hire systematically fewer workers than are interested in working at the high wage level. The two methods of control come to essentially the same thing.

\section{SOURCES OF WAGE DIFFERENTIALS}

To assess the importance of the phenomena cited by the dual theory requires estimates of the quantitative impact of restrictive institutions (including unions) and discrimination. In principle these estimates call for a comparison of employment and wages by occupation before and after reform. The best that I can offer, however, are rough measures of the wage differentials in the economy as it stands, or, rather, as it stood in 1967.

From the same body of data used in my earlier study of unemployment, ${ }^{20}$ I have estimated percentage differentials in wages associated with union membership, employment by government, and occupation. The model underlying these estimates is the following: The wage equals the wage base, as determined by age, education, and other personal characteristics, times (1 plus differential if a union member) times (1 plus differential if employed by government) times (1 plus differential for occupation).

20. The 1967 Survey of Economic Opportunity, conducted by the U.S. Bureau of the Census. For further discussion of this source of data, see my "Wages, Income and Hours of Work." 
I distinguish eight separate union differentials by geographic location (urban and rural areas in four parts of the country), four kinds of government employment (postal, other federal, state, and local), and eleven occupations. The occupational differentials are measured relative to the wages of operatives. I estimated the differentials in the model just stated by defining a regression equation in which the left-hand variable is the natural logarithm of the wage and the right-hand variables are dummy variables for union membership, employment by government, and occupation. The regression coefficients of the dummy variables then are direct estimates of the proportional differentials. Dummy variables for age and years of education (and interactions between them), health, residence at age 16 (foreign or United States), and part-time work are included as determinants of the base wage. Thus the estimated differentials are fully adjusted, for example, for the different age and educational compositions of the union and nonunion groups in the labor force. This study is open to precisely the kind of criticism I directed at Main's study of the effects of training programs: omission of unmeasured characteristics biases the coefficients of the characteristics that are included. I will return to this point shortly.

Estimates were made separately for the four race-sex groups; these results are shown in Table 4. The differentials for union membership are roughly consistent with previous studies, although they are perhaps slightly higher. ${ }^{21}$ In all four regions, the union differential is generally higher in rural than in urban areas. This is especially true for white males. Among the four regions, the union differentials seem to be highest in the South and lowest in the Northeast. The differentials for government employment are positive for fifteen out of the sixteen cases. They tend to be smallest for white males among the four race-sex groups. Finally, except for private household workers, farmers, and farm laborers, the differentials for occupational groups tend to be small, indicating that most of the differences in the average wages by occupation can be explained by differences in personal characteristics.

These estimates of the differentials in wages associated with union membership, government employment, and occupation do not by themselves measure the impact of restrictive institutions on the distribution of earnings among the members of the labor force. The estimate that the wage of a white female union member in the urban North Central region is 20 percent

21. See Harold Gregg Lewis, Unionism and Relative Wages in the United States: An Empirical Inquiry (University of Chicago Press, 1963). 
Table 4. Wage Differentials Associated with Union Membership, Government Employment, and Occupation, by Color and Sex, 1967

Percentage difference

\begin{tabular}{|c|c|c|c|c|}
\hline Characteristic & $\begin{array}{l}\text { White } \\
\text { males }\end{array}$ & $\begin{array}{l}\text { Black } \\
\text { males }\end{array}$ & $\begin{array}{c}\text { White } \\
\text { females }\end{array}$ & $\begin{array}{c}\text { Black } \\
\text { females }\end{array}$ \\
\hline \multicolumn{5}{|l|}{ Union membership } \\
\hline Urban Northeast & $\begin{array}{c}0.12 \\
(0.02)\end{array}$ & $\begin{array}{c}0.11 \\
(0.03)\end{array}$ & $\begin{array}{c}0.09 \\
(0.03)\end{array}$ & $\begin{array}{c}0.00 \\
(0.04)\end{array}$ \\
\hline Rural Northeast & $\begin{array}{c}0.22 \\
(0.60)\end{array}$ & $\cdots$ & $\begin{array}{c}0.18 \\
(0.12)\end{array}$ & $\begin{array}{c}-0.28 \\
(0.55)\end{array}$ \\
\hline Urban North Central & $\begin{array}{l}0.16 \\
(0.02)\end{array}$ & $\begin{array}{c}0.24 \\
(0.03)\end{array}$ & $\begin{array}{c}0.20 \\
(0.04)\end{array}$ & $\begin{array}{c}0.04 \\
(0.04)\end{array}$ \\
\hline Rural North Central & $\begin{array}{c}0.30 \\
(0.04)\end{array}$ & $\ldots$ & $\begin{array}{c}0.21 \\
(0.10)\end{array}$ & $\cdots$ \\
\hline Urban South & $\begin{array}{c}0.24 \\
(0.02)\end{array}$ & $\begin{array}{c}0.34 \\
(0.02)\end{array}$ & $\begin{array}{c}0.24 \\
(0.05)\end{array}$ & $\begin{array}{c}0.22 \\
(0.05)\end{array}$ \\
\hline Rural South & $\begin{array}{c}0.31 \\
(0.03)\end{array}$ & $\begin{array}{c}0.33 \\
(0.06)\end{array}$ & $\begin{array}{c}0.23 \\
(0.08)\end{array}$ & $\begin{array}{c}0.49 \\
(0.11)\end{array}$ \\
\hline Urban West & $\begin{array}{c}0.17 \\
(0.02)\end{array}$ & $\begin{array}{c}0.22 \\
(0.04)\end{array}$ & $\begin{array}{c}0.18 \\
(0.04)\end{array}$ & $\begin{array}{c}0.06 \\
(0.06)\end{array}$ \\
\hline Rural West & $\begin{array}{c}0.29 \\
(0.08)\end{array}$ & $\cdots$ & $\begin{array}{c}0.02 \\
(0.19)\end{array}$ & .. \\
\hline \multicolumn{5}{|l|}{ Government employment } \\
\hline Post Office Department & $\begin{array}{c}0.06 \\
(0.04)\end{array}$ & $\begin{array}{c}0.28 \\
(0.04)\end{array}$ & $\begin{array}{c}0.38 \\
(0.09)\end{array}$ & $\begin{array}{c}0.38 \\
(0.06)\end{array}$ \\
\hline Other federal & $\begin{array}{c}0.22 \\
(0.03)\end{array}$ & $\begin{array}{c}0.25 \\
(0.03)\end{array}$ & $\begin{array}{c}0.27 \\
(0.05)\end{array}$ & $\begin{array}{c}0.22 \\
(0.04)\end{array}$ \\
\hline State & $\begin{array}{c}0.07 \\
(0.04)\end{array}$ & $\begin{array}{c}0.11 \\
(0.08)\end{array}$ & $\begin{array}{c}0.14 \\
(0.06)\end{array}$ & $\begin{array}{c}-0.03 \\
(0.08)\end{array}$ \\
\hline Local & $\begin{array}{c}0.11 \\
(0.03)\end{array}$ & $\begin{array}{c}0.23 \\
(0.05)\end{array}$ & $\begin{array}{c}0.07 \\
(0.03)\end{array}$ & $\begin{array}{c}0.10 \\
(0.06)\end{array}$ \\
\hline \multicolumn{5}{|l|}{ Occupational group } \\
\hline Professional and technical & $\begin{array}{c}0.21 \\
(0.02)\end{array}$ & $\begin{array}{c}0.20 \\
(0.04)\end{array}$ & $\begin{array}{c}0.29 \\
(0.03)\end{array}$ & $\begin{array}{c}0.40 \\
(0.04)\end{array}$ \\
\hline Farmers & $\begin{array}{c}-0.32 \\
(0.10)\end{array}$ & $\ldots$ & $\cdots$ & $\cdots$ \\
\hline Managers, officials, and proprietors & $\begin{array}{c}0.26 \\
(0.02)\end{array}$ & $\begin{array}{c}0.09 \\
(0.05)\end{array}$ & $\begin{array}{c}0.19 \\
(0.04)\end{array}$ & $\begin{array}{c}0.20 \\
(0.08)\end{array}$ \\
\hline Clerical workers & $\begin{array}{c}0.04 \\
(0.02)\end{array}$ & $\begin{array}{c}0.02 \\
(0.03)\end{array}$ & $\begin{array}{c}0.13 \\
(0.02)\end{array}$ & $\begin{array}{c}0.09 \\
(0.03)\end{array}$ \\
\hline Sales workers & $\begin{array}{c}0.08 \\
(0.02)\end{array}$ & $\begin{array}{c}-0.12 \\
(0.06)\end{array}$ & $\begin{array}{c}-0.18 \\
(0.03)\end{array}$ & $\begin{array}{c}-0.12 \\
(0.06)\end{array}$ \\
\hline
\end{tabular}


Table 4 (continued)

\begin{tabular}{lcccc}
\hline \multicolumn{1}{c}{ Characteristic } & $\begin{array}{c}\text { White } \\
\text { males }\end{array}$ & $\begin{array}{c}\text { Black } \\
\text { males }\end{array}$ & $\begin{array}{c}\text { White } \\
\text { females }\end{array}$ & $\begin{array}{c}\text { Black } \\
\text { females }\end{array}$ \\
\hline Craftsmen & 0.16 & 0.11 & 0.01 & 0.07 \\
& $(0.01)$ & $(0.02)$ & $(0.06)$ & $(0.07)$ \\
Operatives & 0.00 & 0.00 & 0.00 & 0.00 \\
Private household workers & $\ldots$ & $\ldots$ & $\ldots$ & $\ldots$ \\
& -0.60 & -0.23 & -0.58 & -0.41 \\
Service workers & $(0.21)$ & $(0.19)$ & $(0.04)$ & $(0.02)$ \\
Farm laborers & -0.15 & -0.16 & -0.19 & -0.11 \\
& $(0.02)$ & $(0.02)$ & $(0.02)$ & $(0.02)$ \\
Other laborers & -0.43 & -0.46 & -0.47 & -0.39 \\
& $(0.03)$ & $(0.03)$ & $(0.13)$ & $(0.06)$ \\
Number of observations & -0.07 & -0.04 & -0.16 & -0.05 \\
Standard error of percentage differential & 0.409 & 0.371 & 0.443 & 0.389 \\
\hline
\end{tabular}

Source: Estimated by author from the 1967 Survey of Economic Opportunity conducted by the U.S. Bureau of the Census, unpublished tabulations. Data are for all private wage and salary workers and government employees. Standard errors appear in parentheses.

higher than the wage of a similar woman who is not a union member tells little about the effect of unions without information about the proportion of these women who are members of unions. In order to give a systematic account of the total impact of restrictive institutions, I have calculated the frequency distribution of the wage differentials received by all of the members of the labor force. This distribution appears in Figure 1 for the effects of union membership and government employment (but not occupation) on the earnings of the entire labor force and of the four race-sex groups. The results for the entire labor force show that 78 percent of all workers receive essentially no benefit ( 0.0 to 0.10 differential) from these two restrictive institutions, while 8 percent of all workers receive a differential of more than 0.20 . The disaggregation by race-sex groups shows that almost all of the benefits accrue to men: 91 percent of white females and 94 percent of black females receive differentials of 0.10 or lower. For men, differences between races are not conspicuous. A slightly lower proportion of black males receives a differential of 0.10 or lower, but the average is somewhat higher for blacks than for whites. Taken together, the results of Figure 1 do not support the hypothesis that the two restrictive institutions, unions and civil service, divide the labor force into primary and secondary sectors. Rather, 
Figure 1. Frequency Distribution within the Labor Force of Wage Differentials Associated with Union Membership and Government Employment, by Color and Sex, 1967

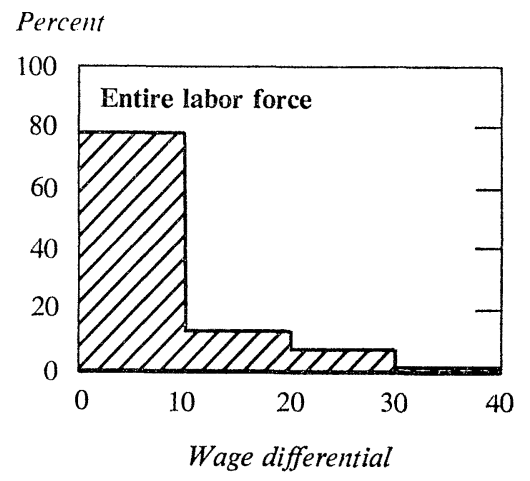

Percent

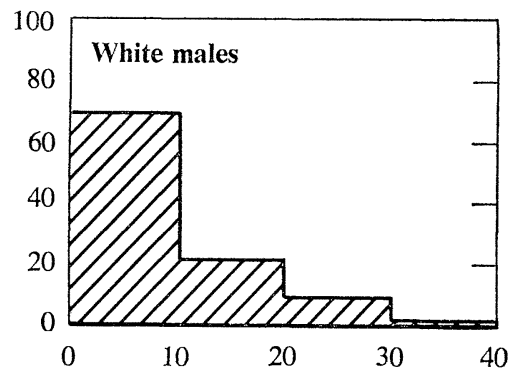

Wage differential

Percent

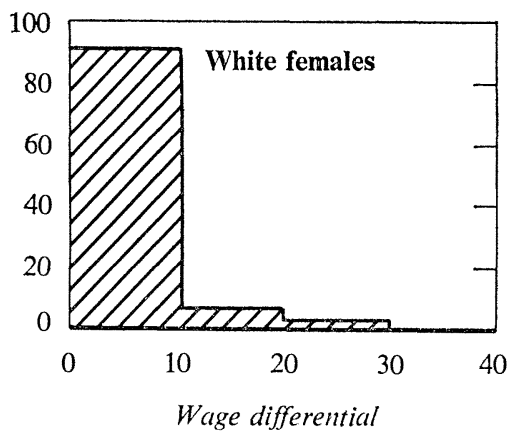

Percent

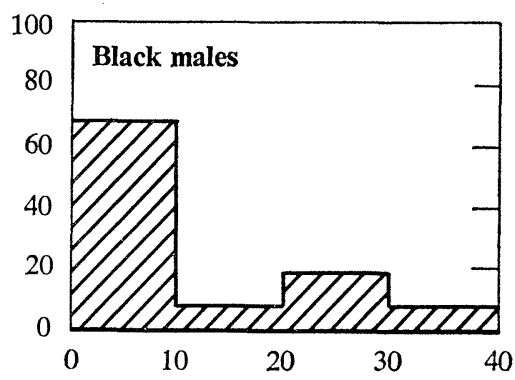

Wage differential

Percent

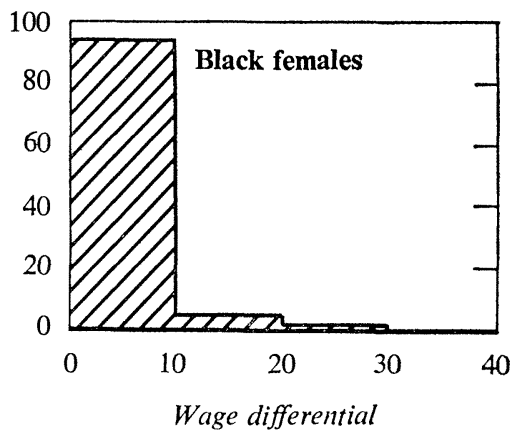

Source: Calculated from the regression coefficients of Table 4 by applying the weights reported in the Survey of Economic Opportunity for inflating the data to levels for the total U.S. population. 
these institutions seem to provide certain limited benefits to a fairly small proportion of the male labor force.

The estimated differentials by occupational groups measure less precisely the effects of restrictive institutions. To some extent, the fact that black male craftsmen receive wages 18 percent higher than those of black operatives merely indicates unmeasured differences between the individuals who are craftsmen and those who are operatives. ${ }^{22}$ On the other hand, part of the differential must be attributed to the restrictive institutions associated with more highly paid occupations-for example, occupational licensing in the case of craftsmen. A treatment of occupational differences in wages that attributes them all to restrictive institutions gives an upper bound to the impact of these institutions.

Distributions of wage differentials including occupational differentials in the labor force appear in Figure 2. These distributions are much more favorable to the hypothesis of the dual labor market. Within the entire labor force, the differentials are distributed roughly symmetrically around zero, and do not cluster at zero. These results are consistent with the notion of an important secondary sector in the labor market in which workers do not receive the protection of restrictive institutions associated with occupation. It does not appear to be feasible to make separate estimates of the effect of identifiable restrictive institutions. Those included in Figure 2unions and the civil service-contribute relatively little to the dispersion of the distributions of wage differentials. The dual theory remains simply a persuasive conjecture without strong empirical support.

\section{The JOBS Program}

In 1968 President Johnson announced a large-scale response to the demand for more jobs, in the form of a program called Job Opportunities in the Business Sector, or JOBS. The idea was to stimulate employers, through subsidy and exhortation, to offer good jobs to workers who were previously unable to find them. A private organization, the National Alliance of Businessmen (NAB), was created for the purpose of locating prospective employers, and funds were made available through the Manpower Administration to subsidize employers by paying the extra costs of training and

22. U.S. Bureau of the Census, Current Population Reports, Series P-60, No. 80, "Income in 1970 of Families and Persons in the United States" (1971), p. 120. 
Figure 2. Frequency Distribution within the Labor Force of Wage Differentials Associated with Union Membership, Government Employment, and Occupation, by Color and Sex, 1967

Percent

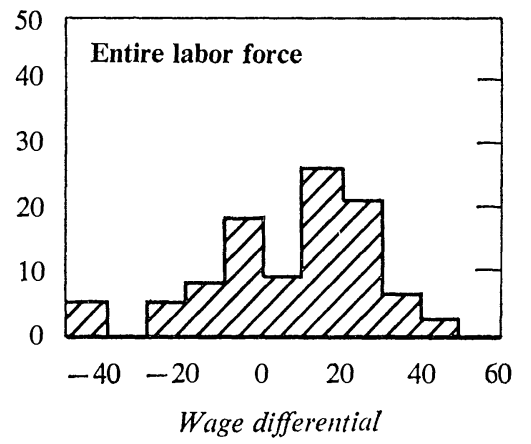

Percent

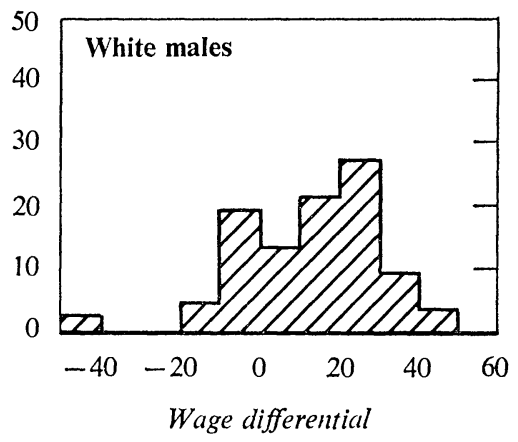

Percent

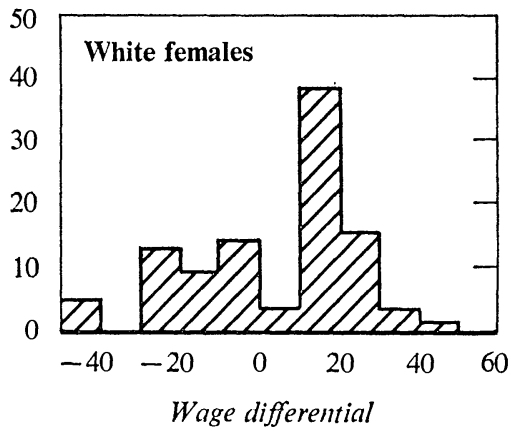

Source: See Figure 1.
Percent

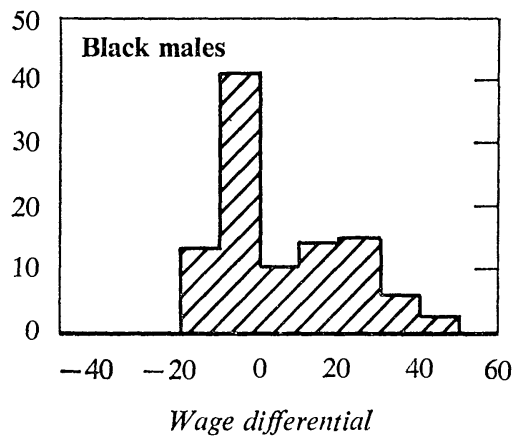

Percent

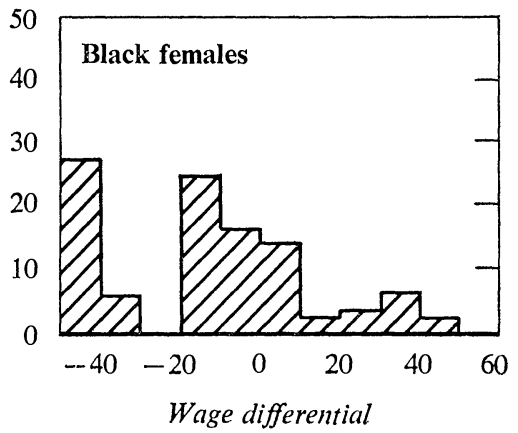


other expenses incurred in the first few months of employment of the disadvantaged and hard-core unemployed workers. This program is worth studying in detail, since the present administration has chosen JOBS as the central part of its manpower program.

JOBS is a strikingly large program. Between March 1968 and September $1970,560,000$ workers were hired under its provisions. ${ }^{23}$ There is no reason to suppose, however, that anywhere close to this number of workers were placed in good jobs. No systematic data have been published on the nature of the jobs filled under the program, and until recently at least, no working system existed for collecting the data from employers. An investigator from the General Accounting Office stated: "We reviewed the files of 158 companies [in San Francisco] that pledged jobs in 1968 and 324 that pledged jobs in 1969, and found that 26 (16.4 percent) and 33 (10.2 percent), respectively, were offering jobs which appeared to be in high-turnover occupations involving minimum skills and low wages. These included employment as janitors, messengers, maids, porters, dishwashers, busboys, potwashers, copy boys, and bar assistants, many of which were at wage rates of less than $\$ 2.00$ an hour." ${ }^{24}$ A large portion of the rest of the jobs are apparently only just above this level. Concern about the quality of the jobs has led recently to the development of a formal "Occupational Opportunities Rating System," which is used to rule out JOBS projects "offering jobs below minimum standards of skill content, potential progress, and stability." ${ }^{25}$

JOBS consists of two distinct programs. The first involves on-the-job training subsidized through contracts with the Manpower Administration. The second is totally unsubsidized. In both cases, the NAB is responsible for locating employers who are willing to take on disadvantaged workers. The subsidy paid in the contract part of the program is relatively small, averaging nationally between $\$ 2,500$ and $\$ 3,000$ per trainee ${ }^{26}$ and about 75 percent of the jobs filled under the program have been in the noncontract part. ${ }^{27}$ The Manpower Administration has consistently failed to spend its

23. Manpower Report of the President, April 1971, p. 44.

24. "Prepared Statement of Henry Eschwege, Associate Director, Civil Division, U.S. General Accounting Office, Washington, D.C.," in Manpower Development and Training Legislation, 1970, Hearings before the Subcommittee on Employment, Manpower, and Poverty of the Senate Committee on Labor and Public Welfare, 91 Cong. 1 and 2 sess. (1970), Pt. 4, p. 2226.

25. Manpower Report of the President, April 1971, p. 44.

26. "Statement of Henry Eschwege," p. 2228.

27. Ibid., p. 2219. 
appropriation for training contracts under JOBS, often by wide margins: Of the $\$ 624$ million appropriated for JOBS between March 1968 and the end of February 1970, just over half ( $\$ 348$ million) had been obligated and less than a sixth ( $\$ 96.9$ million) had actually been paid to contractors. ${ }^{28} \mathrm{Ap}-$ parently some of the contracts have involved an unrealistically large number of training slots, and payments under these contracts (based on the actual number of days of training) are well under the original amount of the contract. ${ }^{29}$

The absence of suitable data makes it difficult to appraise JOBS as a program for offering good jobs to disadvantaged workers. My tentative impression, however, is that the overall impact of the program is very much smaller than is suggested by the number of workers enrolled in it. Underneath its modern dress of "job development" and "sensitivity training," the contract part of JOBS is no more than a conventional training program, suffering from all of the defects of these programs and another large one besides: The contractors often have no previous experience in operating training programs. Since the contracts pay only for the costs of training, and do that only for a few months, the program does nothing to induce employers to offer good jobs. The unsubsidized noncontract part of JOBS seems to operate in the following way: An executive of a large enterprise becomes enthusiastic about the program and inaugurates a policy to employ disadvantaged workers in good jobs under a carefully arranged program with extensive supportive services. Programs of this kind are, I think, the one clear success of JOBS, although it should be recognized that many large employers had already begun to undertake this kind of activity well before JOBS was created. The enthusiastic executive also becomes a missionary for JOBS. Through the NAB, he solicits pledges from other employers to do the same kind of thing. But many of the other employers, especially small ones, have neither the enthusiasm nor the means to run serious programs. The path of least resistance is to make a pledge and to fulfill it by employing disadvantaged workers in the same kinds of jobs they have had in the past. Reliance on altruism seems to work mainly in big business. JOBS does not seem to have been successful, through either persuasion or subsidy, in inducing employers other than very large corporations to offer good jobs to disadvantaged or secondary workers.

28. Ibid.

29. Ibid., p. 2229. 


\section{Public Employment}

The disappointing record of JOBS in trying to induce private employers to provide more good jobs has caused attention to turn to an alternative policy, the creation of jobs directly in the government. In discussion of proposals of this kind, the distinction between movements along the Phillips curve and shifts of the curve itself is especially important. Many of the proposals of the past year (with 6 percent unemployment) amount to almost pure movement along the Phillips curve, in that they provide temporary employment for unemployed workers in general. This kind of increase in the demand for labor is probably just as inflationary as any other, and would put the economy at a point of lower unemployment and higher inflation that could also be achieved by a variety of other policies for stimulating demand. Until August 15, 1971, the administration argued that general stimulation of the economy was inappropriate. Consistent with this view, the President vetoed the Employment and Manpower Act of 1970 , which provided about $\$ 3$ billion for subsidizing employment in state and local governments.

Congress had, in fact, embodied in the law some restrictions that made its effect on the demand for labor selective enough, in principle, to create less inflation per point of reduction in the unemployment rate than would a policy of general stimulation of demand through monetary or fiscal policy. These provisions were strengthened in a new bill, the Emergency Employment Act of 1971, which the President signed in July 1971. It provides $\$ 2.25$ billion for jobs in state and local governments. It has the following provisions designed to have a selective effect on the demand for labor:

1. The jobs must lead to permanent employment (not necessarily in government) and must be in fields that will have increased demand in the future. The administration has been adamant that the program not create what it calls "dead-end" jobs. On the other hand, the law expires in two years, so the governments have to be prepared to finance the new jobs fairly soon, or to place workers in private industry.

2. Workers must have been previously unemployed or underemployed, except for supporting personnel. Preference is to be given to veterans of the war in Vietnam, welfare recipients, participants in training programs, and disadvantaged workers in general. 
3. Professionals may account for no more than a third of total employment in the program of any single government. Each may be paid no more than $\$ 12,000$.

4. The new jobs must represent an actual increase in the number of jobs in existence and federal funds may not displace other funds.

Powerful forces exist to translate the effect of this law into a movement along the Phillips curve, rather than a shift in the curve, in spite of the provisions just listed. In the first place, a two-year subsidy is not a satisfactory method for inducing governments to offer permanent jobs. If, even at full employment, there is already a shortage of good jobs in the private economy, the effects of this policy as a training program will be small. The fundamental defect of the law is its failure to have any long-run impact on the demand for labor. Even in the short run, the intent of the law will be subverted. The only compulsory restriction on the kind of workers hired under the Emergency Employment Act is that they must be unemployed or underemployed at the time they are hired (even this does not apply to administrative and other higher-level personnel). With 6 percent of the labor force now unemployed, including an atypical proportion of workers laid off from good jobs, this requirement imposes hardly any constraint on hiring. State and local governments will hire exactly the same workers who would be hired in the private economy if there were a general expansion in demand, so in this respect the law will induce no shift at all in the Phillips curve. Some of the other restrictions on the character of the new employment may have favorable effects on the composition of demand, depending on how they are enforced. If governments can meet the requirement for hiring disadvantaged workers by increases in the number of janitors hired, for example, these requirements will come to nothing.

It appears that the Emergency Employment Act is mainly a policy to reduce unemployment by moving along the Phillips curve, in spite of the administration's attempts to make it something else. It competes with other policies for expanding demand, perhaps with a slight advantage, but cannot serve as a model for federal policy for shifting the composition of the demand for labor in a way that is favorable for disadvantaged workers. In the concluding section of this paper I discuss briefly the form that a program for bringing about a true shift in the composition of demand might take. This program, contractual in form, would be suitable for inducing employment in state and local governments as well as by private employers. 


\section{Experience with the Creation of Good Jobs}

A number of large corporations have instituted programs for offering good jobs to disadvantaged workers. The experiences of several of these are reviewed in a volume edited by Peter B. Doeringer, ${ }^{30}$ covering Western Electric, IBM, Westinghouse, Equitable Life Assurance, and General Electric. Of these, I will discuss Edward Banfield's chapter on IBM $^{31}$ because it presents data on the cost of the program as well as an evaluation of its effect. IBM's plan was to offer employment in a modern industrial environment to workers whose previous experience was in low-paying, unstable jobs. It opened a plant in the Bedford-Stuyvesant section of Brooklyn and recruited production workers for it locally. Unskilled workers were offered relatively low starting wages, $\$ 2.12$ per hour plus substantial fringe benefits, but IBM made it clear that the jobs were secure and offered definite chances for promotion. It was apparent that there was a shortage of this kind of job, since IBM received 2,565 applications for the 87 positions that were filled in the summer and fall of 1968. Selection from among the applicants was explicitly on the basis of expected productivity, mainly because IBM wanted to be able to promote the new workers rapidly. Still, for many of the workers hired, the jobs with IBM were obviously very much better than the other jobs open to them. For example, 19 percent of the men selected had been in prison and 35 percent of the men and 64 percent of the women had been unemployed for six weeks or more before applying.

In spite of the data on costs and productivity presented by Banfield, it is difficult to estimate how much it cost IBM to produce in the new plant rather than in its established suburban plants. Before the plant began operation, its manager estimated that it would cost $\$ 500,000$ per year for the first few years, with an average employment of about 300 local workers. This is under $\$ 2,000$ per worker per year and includes the cost of on-the-job training, so it compares favorably to the average cost of training under JOBS. Banfield reports that the productivity of the workers in BedfordStuyvesant rose from a fifth of that of ordinary workers to half within a few months, and that it appeared likely to rise further as additional learning

30. Programs To Employ the Disadvantaged (Prentice-Hall, 1969).

31. "An Act of Corporate Citizenship." 
took place. Since the new workers were paid less than the experienced workers at other plants, the cost of the direct labor input at the new plant was not very much greater than the cost at the old plants. However, most of IBM's costs are indirect, and it is difficult to compare these costs between the plants; for one example, the new plant used the medical services of IBM's Manhattan office without charge. High-level executives spent considerable time in organizing and supervising the new plant, which again was not charged specifically to it. My rough impression from Banfield's discussion is that the program cost $\$ 3,000$ or $\$ 4,000$ per worker per year in the actual cost of the operation, imputed costs of services received from other parts of IBM, and forgone profits.

IBM's new employees seem to have reacted favorably to their new jobs. Turnover was less than expected: Out of an average labor force of about fifty in the first six months, there were two quits and three firings. Absenteeism, which was about the same as at IBM's suburban plants, was far less than expected. In general, there seems to be little evidence that the employees brought the pathological conditions of their previous employment with them to IBM. Although the benefits of the program are hard to quantify, it is quite clearly feasible, if at a fairly high price, to provide good jobs to selected members of a group in the labor force whose previous jobs were unstable and low paid. The problem facing the designers of federal manpower policy is to discover a way to persuade employers to engage in programs of this kind on a vastly larger scale.

\section{Conclusions}

The tone of my survey of alternative proposals for shifting the Phillips curve has been generally negative. I found little evidence that a large expansion of existing programs could accomplish very much. The Employment Service already does a fairly complete job of listing openings in certain sectors of the economy, but is not well suited to other sectors. Neither intensive nor extensive expansion has much prospect for decreasing unemployment. Training programs-both those to increase occupational mobility, as suggested by Holt, and those to make disadvantaged workers more productive - have been a serious disappointment even at their present scale. The conventional program of the MDTA, like the innovative programs of 
the CEP and JOBS, suffers from excessive turnover and an inability to place its graduates in good jobs.

The hypothesis that the basic problem in the labor market is a shortage of good jobs seems capable of explaining the failure of conventional manpower policy and suggests, in its place, policies to provide good jobs to disadvantaged workers. Two recent federal policies that seem to have this objective, embodied in JOBS and the Emergency Employment Act of 1971, fail for opposite reasons-in the first case because JOBS does not generally offer good jobs, and in the second because the Emergency Employment Act jobs probably will not go to disadvantaged workers.

The main ray of hope in my survey is the apparent success of limited programs to offer good jobs in large firms to disadvantaged workers. The actions of these firms suggest that they have a certain amount of social conscience and thus a certain commitment to the goal of helping the disadvantaged, and are less susceptible to the pressures undercutting programs than are businesses and governments that act purely in their own interests. It is probably neither feasible nor desirable for government policy to try to foster the development of social conscience elsewhere in the economy, especially since that which exists now has an uncanny correlation with monopoly power. The problem at hand, then, is to design a federal program that makes it in an employer's own interest to offer good jobs to disadvantaged workers.

There are, I think, three basic kinds of policies to accomplish this: federal contracts, taxes, and employment quotas. Contracts with the Manpower Administration have been the form through which the federal part of JOBS has been administered, and the experience of that program is suggestive of the advantages and disadvantages of administration through contracts. In principle, contracting is a powerful and flexible tool for imposing federal policy on businesses and governments. Plans are reviewed in advance and no applicant receives a contract as a matter of right. In JOBS, at least, very few of the advantages of contracting are realized, however. Payment is for direct expenses of training, including a limited allowance for wages during on-the-job training. The result has been to stimulate expenditures on peripheral training that has identifiable costs and to discourage employment in jobs where there is any gap between the wage paid and the productivity of disadvantaged workers. It seems to me that the principle of reimbursement for costs should be purged entirely from federal contracts for developing good jobs. It has hurt JOBS very badly by making 
the contracts so unattractive that the Manpower Administration has been able to negotiate only relatively few, and those only by imposing almost no standards on the nature of the jobs they cover. If this requirement were eliminated, and the government were instead to pay an explicit subsidy large enough to make the contracts attractive, strong standards could be imposed on both the nature of the jobs created and on the kind of workers chosen to fill them. Since one of the main purposes of this program would be to create a stronger attachment between job and worker, contracts could contain specific provision rewarding an employer for reducing turnover in his work force.

Table 5 presents estimates of the cost and impact of a contractual employment program of realistic scale. The proposed program would last three years for each job and would subsidize the job by $\$ 4,000$ in the first year, $\$ 3,000$ in the second, and $\$ 2,000$ in the third. My estimates assume an attrition rate of 20 percent per year, very much lower than the rates in existing training programs, but higher than those reported for the programs of large corporations. They assume that the new workers are drawn from a population with a 10 percent unemployment rate, that unemployment is nonexistent among the workers covered by the contracts, and that the newly created job-worker combinations are associated with a 4.5 percent unemployment rate after completion of the program. ${ }^{32}$ The estimated impact of the program is small. Many years of operation would be required to reduce the unemployment rate by even 0.1 percentage point, say from 4.5 to 4.4 percent. A scale two or three times larger than that assumed in Table 5 might yield a proportionately larger decrease in unemployment, but this kind of contractual program seems unlikely to achieve any substantial reduction in unemployment. As the program expanded, it would become increasingly difficult to find productive activities suitable for upgrading or expansion that were not protected by powerful interests. It would take more than the kind of contract proposed here to open up additional good jobs in the building trades, for example.

A comprehensive tax policy seems to be an attractive alternative to a contractual program exactly because of its large scale. The provisions of the federal tax on corporate income automatically influence the behavior

32. Note that unemployment is assumed to fall not by the total number of jobs created but by 10 percent of those employed under the program and 5.5 percent of those who complete it. This embodies the main point of view of the paper that all calculations of reductions in unemployment are standardized for inflationary pressure. 


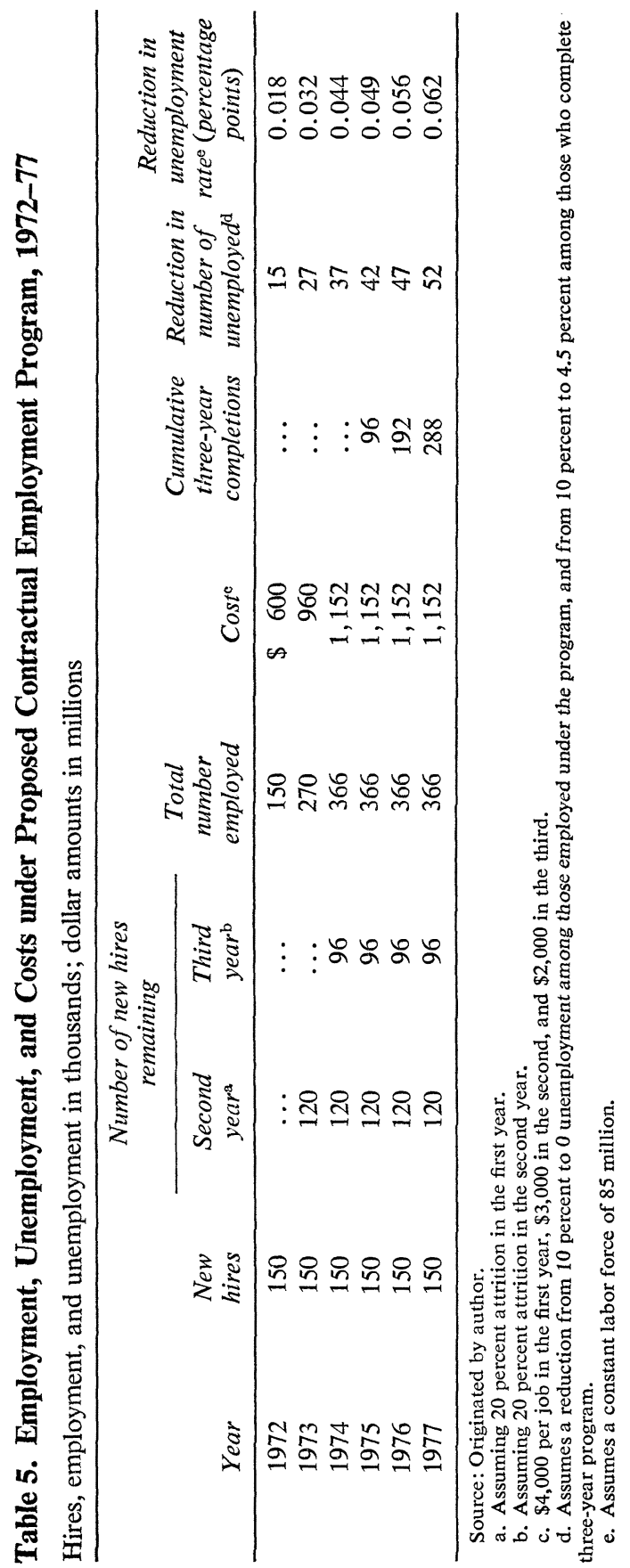


of every business in the country of any size. The tax credit on investment provides a natural model for this kind of policy. The difficulty in designing a tax policy for shifting the Phillips curve lies in the subtlety of the goal. Throughout its history, the investment credit has been used mainly as a countercyclical device; it has been put on and taken off in attempts to avoid under- and over-full employment, as an alternative to or in conjunction with decreases or increases in tax rates. A credit on employment could be used for the same purpose. But policies of this sort induce movements along the Phillips curve, not shifts of the curve itself. What is needed is a highly selective tax to bring about a shift in the composition of the demand for labor. This might take the form of a tax credit for long-term employment of disadvantaged workers. Enforcement of the tax laws would require a method for certifying workers eligible for the credit; this would probably involve the Manpower Administration. There does not seem to be any large difference between administration through the tax system and through contracts.

Instead of inducing employers to offer more good jobs, the federal government might consider compelling them to do it. In a system of compulsion through employment quotas it would be difficult and dangerous to formulate precise but complicated definitions of who the disadvantaged workers were and what kind of job should be opened up for them. For example, it is appropriate to reward an employer for keeping a worker on the job for more than two years but it would be catastrophic to require him to keep all of his workers that long. The theory of statistical discrimination suggests a simple answer to the problem of formulating quotas: If easily observed characteristics are highly correlated with inability to find good jobs, the quotas should be stated in terms of these characteristics. In practical terms this means setting employment quotas for women and for racial minorities. A fairly detailed proposal for a policy of this kind has been made by John Kenneth Galbraith, Edwin Kuh, and Lester C. Thurow. ${ }^{33}$ They propose that all employers with more than 2,000 employees be required, within ten to thirteen years (depending on firm size), to employ women, blacks, and Spanish-speaking workers in proportion to their presence in the labor force. Further, in order to guard against balancing black janitors and female typists, for example, against white male executives, they would require that the appropriate ratios prevail in each wage

33. "The Galbraith Plan To Promote the Minorities," The New York Times Magazine (August 22, 1971), p. 9. 
class as well as overall. Thus about one-third of all jobs paying more than five dollars per hour would have to be held by women, and one-eighth of them by blacks. Undoubtedly, this policy would have a substantial impact on the Phillips curve: If the unemployment rates of women and of blacks could be reduced to the level of white males, the overall rate would drop by between 1.0 and 1.5 percentage points. This policy far transcends the scope of manpower policy and seems remote from political feasibility.

What, then, might realistically be done to shift the Phillips curve? Among the manpower programs discussed in this paper, none seems capable of bringing about a substantial reduction in the amount of unemployment observed at a given rate of inflation. Programs for streamlining the operation of the labor market might induce a small shift in the Phillips curve of perhaps 0.2 percentage point in the unemployment rate. An expanded federal policy directed particularly at teenagers might bring about another shift of about the same magnitude. Beyond this, programs for training or for subsidized employment do not seem capable of inducing a perceptible shift in the Phillips curve.

This paper and that by Holt and associates that follows were discussed together. The discussion begins on page 723 below. 